Marquette University

e-Publications@Marquette

Biological Sciences Faculty Research and

Publications

Biological Sciences, Department of

$6-2010$

\title{
Bioaugmentation for Improved Recovery of Anaerobic Digesters After Toxicant Exposure
}

Anne Schauer-Gimenez

Marquette University

Daniel Zitomer

Marquette University

James Maki

Marquette University, james.maki@marquette.edu

Craig Struble

Marquette University

Follow this and additional works at: https://epublications.marquette.edu/bio_fac

Part of the Biology Commons

\section{Recommended Citation}

Schauer-Gimenez, Anne; Zitomer, Daniel; Maki, James; and Struble, Craig, "Bioaugmentation for Improved Recovery of Anaerobic Digesters After Toxicant Exposure" (2010). Biological Sciences Faculty Research and Publications. 69.

https://epublications.marquette.edu/bio_fac/69 


\title{
Bioaugmentation for Improved Recovery of Anaerobic Digesters after Toxicant Exposure
}

\author{
Anne E. Schauer-Giminez \\ Department of Civil and Environmental Engineering \\ Water Quality Center, Marquette University, \\ Milwaukee, WI \\ Daniel H. Zitomer \\ Department of Civil and Environmental Engineering \\ Water Quality Center, Marquette University, \\ Milwaukee, WI \\ James S. Maki \\ Department of Biological Sciences, Marquette University, \\ Milwaukee, WI \\ Craig A. Struble \\ Department of Mathematics, Statistics and Computer Science, \\ Marquette University
}

\begin{abstract}
:
Bioaugmentation was investigated as a method to decrease the recovery period of anaerobic digesters exposed to a transient toxic event. Two sets of laboratory-scale digesters (SRT $=10$ days, OLR $=2 \mathrm{~g} \mathrm{COD} / \mathrm{L}-$ day), started with inoculum from a digester stabilizing synthetic municipal wastewater solids (MW) and synthetic industrial wastewater (WW), respectively, were transiently exposed to the model toxicant, oxygen. Bioaugmented digesters received $1.2 \mathrm{~g}$ VSS/L-day of an $\mathrm{H}_{2}$-utilizing culture
\end{abstract}

Water Research, Vol. 44, No. 12 (June 2010): pg. 3555-3564. DOI. This article is @ Elsevier and permission has been granted for this version to appear in e-Publications@Marquette. Elsevier does not grant permission for this article to be further copied/distributed or hosted elsewhere without the express permission from Elsevier. 
for which the archaeal community was analyzed. Soon after oxygen exposure, the bioaugmented digesters produced $25-60 \%$ more methane than nonbioaugmented controls $(p<0.05)$. One set of digesters produced lingering high propionate concentrations, and bioaugmentation resulted in significantly shorter recovery periods. The second set of digesters did not display lingering propionate, and bioaugmented digesters recovered at the same time as nonbioaugmented controls. The difference in the effect of bioaugmentation on recovery may be due to differences between microbial communities of the digester inocula originally employed. In conclusion, bioaugmentation with an $\mathrm{H}_{2}$-utilizing culture is a potential tool to decrease the recovery period, decrease propionate concentration, and increase biogas production of some anaerobic digesters after a toxic event. Digesters already containing rapidly adaptable microbial communities may not benefit from bioaugmentation, whereas other digesters with poorly adaptable microbial communities may benefit greatly.

\section{Introduction}

Bioaugmentation is the practice of adding specific microorganisms to a system to enhance a desired activity (Rittmann and Whiteman, 1994; Deflaun and Steffan, 2002). In wastewater treatment, bioaugmentation has most frequently been applied to aerobic systems to increase the population of nitrifying bacteria after upsets from uncontrolled biomass loss, fluctuations in $\mathrm{pH}$, toxic events, or temperature decrease (Rittmann and Whiteman, 1994; Abeysinghe et al., 2002; Satoh et al., 2003; Head and Oleszkiewicz, 2005). Bioaugmentation has also been used for other aerobic applications, including improved flocculation and degradation of specific substrates (Van Limbergen et al., 1998), and for soil and groundwater bioremediation (Deflaun and Steffan, 2002; Singer et al., 2005).

For anaerobic processes, bioaugmentation has been investigated at laboratory scale to improve start-up of new digesters(Saravanane et al., 2001a,b), odor reduction (Duran et al., 2006; Tepe et al., 2008), and recovery after organic overload (Lynch et al., 1987). Also, anaerobic degradation rates of phenol and cresol (Charest et al., 1999; Tawfiki Hajji et al., 1999; Guiot et al., 2000;Tawfiki Hajji et al.,2000), pentachlorophenol (Tartakovsky et al., 1999; Guiot et al., 2002), 3chlorobenzoate (Ahring et al., 1992), tetrachloroethylene (Horber et

Water Research, Vol. 44, No. 12 (June 2010): pg. 3555-3564. DOI. This article is @ Elsevier and permission has been granted for this version to appear in e-Publications@Marquette. Elsevier does not grant permission for this article to be further copied/distributed or hosted elsewhere without the express permission from Elsevier. 
al., 1998) and fat, oil and grease (Cirne et al., 2006) have been increased using bioaugmentation. Anaerobic bioaugmentation with cellulose degraders increased methane production rates from hemicellulose by 30\% (Angelidaki and Ahring, 2000) and cattle manure by as much as 93\% (Mladenovska et al., 2001; Nielsen et al., 2007); however, the significant increase in methane yield was only sustained for a limited time after inoculation. The short improvement period highlights current challenges such as washout and outcompetition by indigenous organisms associated with bioaugmentation approaches (El Fantroussi and Agathos, 2005).

Bioaugmentation for rapid recovery of anaerobic digesters exposed to transient toxicants has not been reported to our knowledge. However, it may be advantageous to develop bioaugmentation as a recovery tool to address transient toxicity that can occur in full scale. Production and distribution of individual bioaugmentation cultures, each enriched to degrade a specific substrate, would be time consuming. It may be more practical to target a key, ubiquitous intermediate that accumulates during toxic events. In this regard, hydrogen $\left(\mathrm{H}_{2}\right)$ is a reasonable target intermediate since its degradation is often a rate-limiting step in methane production from many complex substrates. The $\mathrm{H}_{2}$ concentration in anaerobic systems must be very low ( $<50 \mathrm{mM}$ ) for conversion of propionate and other intermediates to methane to be thermodynamically spontaneous (McCarty and Smith, 1986). Therefore, more rapid $\mathrm{H}_{2}$ utilization can result in more complete conversion of propionate and other substrates to methane. In this study, bioaugmentation using an $\mathrm{H}_{2}$-utilizing culture was tested to determine if the approach would decrease the recovery time of anaerobic digesters exposed to a transient toxic event. A limited amount of the model toxicant, oxygen $\left(\mathrm{O}_{2}\right)$, was added to different digesters for a short period, and recovery of bioaugmented and nonbioaugmented digesters was compared.

Water Research, Vol. 44, No. 12 (June 2010): pg. 3555-3564. DOI. This article is @ Elsevier and permission has been granted for this version to appear in e-Publications@Marquette. Elsevier does not grant permission for this article to be further copied/distributed or hosted elsewhere without the express permission from Elsevier. 
NOT THE PUBLISHED VERSION; this is the author's final, peer-reviewed manuscript. The published version may be accessed by following the link in the citation at the bottom of the page.

\section{Materials and methods}

\subsection{Anaerobic digesters}

Two sets of anaerobic digesters were operated. Sets differed based upon the source of the initial inoculum employed. One set (MS systems) was inoculated with biomass from a bench-scale mesophilic anaerobic digester fed synthetic municipal sludge (Natural Choice Dog Food, NutroProducts, Inc., City of Industry, CA) with a 10-day solids retention time (SRT). The other set (WW systems) was inoculated with biomass from a bench-scale mesophilic anaerobic digester fed synthetic industrial wastewater (Instant Nonfat Dry Milk, Roundy's, Inc., Milwaukee, WI) with a15-day SRT.

All digesters were $160-\mathrm{mL}$ serum bottles containing $50 \mathrm{~mL}$ of active volume and operated at an SRT of 10 days and organic loading rate of $2 \mathrm{~g} \mathrm{COD/L-day.} \mathrm{Five} \mathrm{mL} /$ day of effluent was removed and replaced with $5 \mathrm{~mL} /$ day of synthetic wastewater composed of nonfat dry milk (Roundy's Instant Nonfat Dry Milk) in basal nutrient medium. After one week, all digesters were exposed to the model toxicant, $\mathrm{O}_{2}$, by injecting $10 \mathrm{~mL} /$ day of air (approximately $1 \mathrm{~atm}, 20^{\circ} \mathrm{C}$ ) into each system for seven days. Bioaugmented digesters received $1.2 \mathrm{mg}$ of volatile suspended solids (VSS) per liter of digester per day ( $\mathrm{mg}$ VSS/L-day) of an enrichment culture described below. Control digesters received an abiotic version of the enrichment culture that had been inactivated by autoclaving.

\subsection{Culture used for bioaugmentation}

The methanogenic culture used for bioaugmentation was developed using biomass from a mesophilic municipal anaerobic digester (South Shore Wastewater Treatment Plant, Milwaukee, WI) treating primary sludge and was enriched by feeding $\mathrm{H}_{2}$, carbon dioxide $\left(\mathrm{CO}_{2}\right)$, and glucose in the basal medium as well as limited $\mathrm{O}_{2}$ over three months. Two liters of biomass were maintained in a $2.5-\mathrm{L}$ glass reactor continuously stirred with a magnetic stir bar and in a temperature-controlled room $\left(35 \pm 2{ }^{\circ} \mathrm{C}\right)$. The culture was sparged daily with gas $\left(1: 1 \mathrm{v} / \mathrm{v} \mathrm{H}_{2}: \mathrm{CO}_{2}\right)$ for approximately $20 \mathrm{~s}$ and sealed with a rubber stopper. The $\mathrm{CO}_{2}$ content was greater than that of the

Water Research, Vol. 44, No. 12 (June 2010): pg. 3555-3564. DOI. This article is @ Elsevier and permission has been granted for this version to appear in e-Publications@Marquette. Elsevier does not grant permission for this article to be further copied/distributed or hosted elsewhere without the express permission from Elsevier. 
stoichiometric amount (i.e., 4:1 v/ $\mathrm{v} \mathrm{H}_{2}: \mathrm{CO}_{2}$ ) so as to maintain the culture $\mathrm{pH}$ near 7. A glass tube was inserted through the stopper and connected to a 5-L Tedlar bag that was emptied daily and refilled with the $\mathrm{H}_{2}: \mathrm{CO}_{2}$ mixture. The liquid effluent $(133 \mathrm{~mL})$ was removed once per day to maintain an SRT and hydraulic retention time (HRT) of 15 days. Effluent was replaced with $133 \mathrm{~mL}$ of basal medium containing $84 \mathrm{mg}$ glucose. Approximately $80 \mathrm{mg} \mathrm{O}$ /day was added by injecting $280 \mathrm{~mL}$ of ambient air (approximately $1 \mathrm{~atm}, 20^{\circ} \mathrm{C}$ ) directly into the vessel headspace with a plastic syringe. This mass of $\mathrm{O}_{2}$ satisfied very little (i.e., 6\%) of the $\mathrm{H}_{2}$ oxygen demand. Therefore, the culture dissolved oxygen concentration was expected to be zero, and the presence of strict anaerobes (e.g., methanogens) was anticipated.

\subsection{Basal nutrient medium}

Basal nutrient medium contained the following [mg/L]: $\mathrm{NH}_{4} \mathrm{Cl}$ [400]; $\mathrm{MgSO}_{4} \cdot 6 \mathrm{H}_{2} \mathrm{O}[250] ; \mathrm{KCl}[400] ; \mathrm{CaCl}_{2} \cdot 2 \mathrm{H}_{2} \mathrm{O}[120] ;\left(\mathrm{NH}_{4}\right)_{2} \mathrm{HPO}_{4}$ [80]; $\mathrm{FeCl}_{3} \cdot 6 \mathrm{H}_{2} \mathrm{O}$ [55]; $\mathrm{CoCl}_{2} \cdot 6 \mathrm{H}_{2} \mathrm{O}$ [10]; $\mathrm{KI}$ [10]; the trace metal salts $\left(\mathrm{MnCl}_{2} \cdot 4 \mathrm{H}_{2} \mathrm{O}, \mathrm{NH}_{4} \mathrm{VO}_{3}, \mathrm{CuCl}_{2} \cdot 2 \mathrm{H}_{2} \mathrm{O}, \mathrm{Zn}\left(\mathrm{C}_{2} \mathrm{H}_{3} \mathrm{O}_{2}\right) 2 \cdot 2 \mathrm{H}_{2} \mathrm{O}, \mathrm{AlCl}_{3} \cdot 6 \mathrm{H}_{2} \mathrm{O}\right.$, $\mathrm{NaMoO}_{4} \cdot 2 \mathrm{H}_{2} \mathrm{O}, \mathrm{H}_{3} \mathrm{BO}_{3}, \mathrm{NiCl}_{2} \cdot 6 \mathrm{H}_{2} \mathrm{O}, \mathrm{NaWO}_{4} \cdot 2 \mathrm{H}_{2} \mathrm{O}$, and $\mathrm{Na}_{2} \mathrm{SeO}_{3}$ ) [each at 0.5$]$; yeast extract [100]; $\mathrm{NaHCO}_{3}$ [5000]; and resazurin [1].

\subsection{Specific methanogenic activity (SMA) assays}

Methanogenic activity assays were conducted in triplicate at 35 ${ }^{\circ} \mathrm{C}, 250 \mathrm{rpm}$ using an incubator shaker (model C25KC, New Brunswick Scientific, Edison, NJ). Published protocols for the substrates calcium acetate (Angelidaki et al., 2007) as well as $\mathrm{H}_{2}: \mathrm{CO}_{2}$ (Coates et al., 1996) were used. All assays were performed under anaerobic conditions in $160 \mathrm{~mL}$ serum bottles with $25 \mathrm{~mL}$ of enrichment culture having 100-400 mg/L VSS. Culture samples were collected from reactors on three consecutive days and composited for testing. The VSS concentration was determined at the beginning and end of activity tests and the average of the two values was employed for specific activity calculations.

For acetate activity assays, the substrate was added to serum bottle contents to achieve $10 \mathrm{~g} / \mathrm{L}$ of calcium acetate. Bottles were then sparged with $\mathrm{O}_{2}$-free gas (7:3 v/v $\mathrm{N}_{2}: \mathrm{CO}_{2}$ ), closed with red butyl

Water Research, Vol. 44, No. 12 (June 2010): pg. 3555-3564. DOI. This article is @ Elsevier and permission has been granted for this version to appear in e-Publications@Marquette. Elsevier does not grant permission for this article to be further copied/distributed or hosted elsewhere without the express permission from Elsevier. 
rubber septa and incubated. For hydrogenotrophic activity assays, serum bottles were sparged with gas $\left(4: 1 \mathrm{v} / \mathrm{v} \mathrm{H}_{2}: \mathrm{CO}_{2}\right)$ and closed with solid Balch-type butyl rubber stoppers (Geo-Microbial Technologies, Inc., Ochelata, OK) and aluminum-crimped seals. Immediately thereafter, $100 \mathrm{~mL}$ of the $\mathrm{H}_{2}: \mathrm{CO}_{2}$ gas blend at ambient pressure and temperature was injected through the stopper using a syringe and 23gauge needle; then the bottles were incubated. Blanks were prepared similarly, but no substrate was added. These bottles were sparged with $\mathrm{H}_{2}$-free gas (7:3 v/v $\left.\mathrm{N}_{2}: \mathrm{CO}_{2}\right)$ and sealed. Bottle headspace volume was measured at ambient pressure (approximately 1 atm) for 1-5 days. Volume was measured by inserting the needle of a glass syringe with wetted barrel. Syringe content was re-injected into the serum bottle after volume measurement. Headspace $\mathrm{CH}_{4}$ content was measured using gas chromatography (GC).

For activity, maximum methane production rate $(\mathrm{mL} \mathrm{CH} / \mathrm{h})$ was determined by linear regression of the initial, linear portion of a plot of cumulative methane production versus time. SMA values $\left(\mathrm{mL} \mathrm{CH}_{4} / \mathrm{g}\right.$ VSS-h) were calculated by dividing maximum methane production rate values by average VSS mass. For hydrogenotrophic activity, maximum methane production rate $\left(\mathrm{mL} \mathrm{CH}_{4} / \mathrm{h}\right)$ was determined as described by others (Coates et al., 1996). Briefly, the decrease in headspace volume observed at any time was corrected by adding the volume of additional gas measured in blanks. The sum was divided by four based upon the stoichiometry of hydrogenotrophic methanogenesis (i.e., for every $4 \mathrm{~mol}$ of $\mathrm{H}_{2}$ and $1 \mathrm{~mol}$ of $\mathrm{CO}_{2}$ consumed, $1 \mathrm{~mol}$ of $\mathrm{CH}_{4}$ is produced) to yield the cumulative volume of methane produced. Maximum methane production rates and SMA values against $\mathrm{H}_{2}: \mathrm{CO}_{2}$ were then determined by linear regression as described for acetate activity.

\subsection{Analytical methods}

Samples for propionate and soluble COD(SCOD) concentration analysis were centrifuged at 14,000 for 10 min (Galaxy 14D centrifuge, VWR International, West Chester, PA) and filtered using a $0.45 \mu \mathrm{m}$ filter (Whatman International Ltd.,Maidstone, England). Propionate was measured in filtrate using a GC (Series 600, GOW-MAC Instrument Co., Bethlehem, MA) equipped with a flame ionized

Water Research, Vol. 44, No. 12 (June 2010): pg. 3555-3564. DOI. This article is @ Elsevier and permission has been granted for this version to appear in e-Publications@Marquette. Elsevier does not grant permission for this article to be further copied/distributed or hosted elsewhere without the express permission from Elsevier. 
detector (FID) and a packed stainless steel column $6^{\prime} 1 / 4^{\prime \prime}$ (Alltech Associates, Inc., Deerfield, IL). Helium was used as the carrier gas at a flow of $50 \pm 1 \mathrm{~mL} / \mathrm{min}$. The temperature of the injector and detector was $200^{\circ} \mathrm{C}$ and the oven temperature was $150^{\circ} \mathrm{C}$. The supernatant was stored in 4-mL vials with a minimal amount of phosphoric acid to acidify the sample to a $\mathrm{pH}$ of $<2$. SCOD was measured in filtrate by standard methods (APHA et al., 1998). The biogas quantity produced in digesters was measured daily using a glass syringe with a wetted glass barrel. The headspace gas composition $\left(\mathrm{CH}_{4}, \mathrm{CO}_{2}\right.$, and $\mathrm{N}_{2}$ concentrations) was determined using a GC equipped with a thermal conductivity detector (TCD) and a packed column (CTR I column, Alltech Associates, Inc., Deerfield, IL). Helium was used as the carrier gas at a flow of $30 \pm 2 \mathrm{~mL} / \mathrm{min}$ with injector and detector temperatures of $120^{\circ} \mathrm{C}$ and oven temperature of $38^{\circ} \mathrm{C}$. The $\mathrm{pH}$ was measured using a bench-top $\mathrm{pH}$ meter (Orion Model 720A, Thermo Fisher Scientific, Inc., Waltham, MA) and a general-purpose $\mathrm{pH}$ electrode (Orion, Thermo Fisher Scientific, Inc., Waltham, MA).

\subsection{Statistical analyses}

All statistical analyses were completed using the "t-test: twosample assuming unequal variances" function in Microsoft Excel (Excel, 2004 for Mac, Version 11.5.5). Each set of replicates was analyzed in order to obtain mean and variance values for the t-test function.

\subsection{Archaeal community analysis}

\subsubsection{DNA extraction}

DNA was extracted from the bioaugmentation culture by removing and centrifuging (IEC Centra-4B, International Equipment Company) a $50-\mathrm{mL}$ volume for $10 \mathrm{~min}$ at 2500 . The supernatant was then decanted and a $0.75-\mathrm{mL}$ thickened biomass sample was used for DNA extraction (PowerSoilTM DNA Isolation Sample Kit, MoBio Laboratories, Carlsbad, CA). The standard protocol provided in the kit was followed with one exception; the Alternative Lysis Method was used (a $1 \mathrm{~min}$ vortex followed by a $10 \mathrm{~min}$ incubation at $70{ }^{\circ} \mathrm{C}$, after adding Solution $\mathrm{C} 1$ ). The presence of DNA was confirmed and estimates of its concentration were made using gel electrophoresis ( $1 \%$ agarose)

Water Research, Vol. 44, No. 12 (June 2010): pg. 3555-3564. DOI. This article is (c Elsevier and permission has been granted for this version to appear in e-Publications@Marquette. Elsevier does not grant permission for this article to be further copied/distributed or hosted elsewhere without the express permission from Elsevier. 
stained with ethidium bromide $(0.8 \mu \mathrm{L} / \mathrm{mL}$ ) (Sambrook and Russell, 2001). A DNA ladder containing 40-ng/ $\mu \mathrm{L}$ Lambda DNA, HindIII cut and in some cases $30-\mathrm{ng} / \mu \mathrm{L}$ phi $\mathrm{X} 174$, HaeIII cut was used as a marker.

\subsubsection{Polymerase chain reaction}

A fragment of the $16 \mathrm{~S}$ rRNA genes was amplified with ArchF (5'TTCCGGTTGATCCYGCCGGA-3') and ArchR (5'YCCGGCGTTGAMTCCAATT-3') (DeLong, 1992) using either a Biometra Tpersonal (Biometra, Goettingen, Germany) or Bio-Rad PTC-200 DNA Engine Cycler thermal cycler (Bio-Rad, Hercules, CA). All PCR amplification mixtures $(100 \mu \mathrm{L})$ contained EconoTaq ${ }^{\circledR}$ PLUS 2X Master Mix (Lucigen Corporation, Middleton, WI) and $0.1 \mu \mathrm{M}$ of each primers. The amplification method parameters were as follows: $94^{\circ} \mathrm{C}$ for $2 \mathrm{~min}$, $94^{\circ} \mathrm{C}$ for $30 \mathrm{~s}, 55^{\circ} \mathrm{C}$ for $30 \mathrm{~s}, 72{ }^{\circ} \mathrm{C}$ for $2 \mathrm{~min}$ for 34 cycles and $72{ }^{\circ} \mathrm{C}$ for $13 \mathrm{~min}$.

\subsubsection{Cloning}

The 16S rRNA gene amplified products were cloned into One Shot ${ }^{\circledR}$ Mach1TM-T1R Chemically Competent Escherichia coli cells using the TOPO TA Cloning ${ }^{\circledR}$ Kit for Sequencing according to the manufacturer's instructions (Invitrogen, Carlsbad, CA). Bacteria were inoculated to S-GalTM/Kanamycin/Luria-Bertani Broth Agar Blend (Sigma-Aldrich, St. Louis, MO) plates containing $50 \mathrm{mg} / \mathrm{mL}$ ampicillin and incubated at $37^{\circ} \mathrm{C}$ for one day. Colonies were picked using light/dark screening and directly amplified with PCR using PucF (5'GGAATTGTGAGCGGATA ACA-3') and PucR (5'GGCGATTAAGTTGGGTAACG-3') primers. The PCR thermal cycling parameters were as follows: $94^{\circ} \mathrm{C}$ for $2 \mathrm{~min}, 94^{\circ} \mathrm{C}$ for $30 \mathrm{~s}, 55^{\circ} \mathrm{C}$ for $30 \mathrm{~s}, 72{ }^{\circ} \mathrm{C}$ for $1 \mathrm{~min}$ for 30 cycles, and $72{ }^{\circ} \mathrm{C}$ for $9 \mathrm{~min}$. The presence of amplified PCR products was confirmed using agarose gel electrophoresis as previously described.

Water Research, Vol. 44, No. 12 (June 2010): pg. 3555-3564. DOI. This article is @ Elsevier and permission has been granted for this version to appear in e-Publications@Marquette. Elsevier does not grant permission for this article to be further copied/distributed or hosted elsewhere without the express permission from Elsevier. 
NOT THE PUBLISHED VERSION; this is the author's final, peer-reviewed manuscript. The published version may be accessed by following the link in the citation at the bottom of the page.

\subsubsection{PCR purification, sequencing and phylogenetic analysis}

Samples were cleaned using the UItraCleanTM PCR Clean-upTM kit according to manufacturers' instructions (MoBio Laboratories, Carlsbad, CA).

PCR products of 50 archaeal clones from the bioaugmentation culture were sequenced (University of Chicago Cancer Research Center DNA Sequencing Facility, Chicago, IL). The forward and reverse sequences were analyzed using FinchTV (Geospira Inc., Seattle, WA) and Vector NTI (Invitrogen, Carlsbad, CA) and consensus sequences were assembled. Vector sequences were removed using the Basic Local Alignment Search Tool (BLAST) to match vector sequences in the UniVec Database with the sample sequences in a manner identical to VecScreen (Altschul et al., 1997). Chimera detection analysis was performed using Chimera Check, version 2.7 (Cole et al., 2005) of the Ribosomal Database Project (RDP) and sequences determined to be chimeras were removed from further analysis.

The complete consensus sequences were submitted to BLAST to identify similar 16S rRNA gene sequences (Altschul et al., 1997). The consensus and select reference sequences were aligned using the RDP (Cole et al., 2007). A distance matrix based on the Kimura 2parameter algorithm was constructed using the Phylogeny Inference Package (PHYLIP) dnadist program (Felsenstein, 2005). Bootstrap analyses were performed to generate 100 bootstrap samples. Neighbor-joining, maximum parsimony and maximum likelihood trees were created using PHYLIP. Consensus trees were generated with PHYLIP's consense program, using the extended majority rule. Resulting trees were visualized using FigTree v1.1.2 (Rambaut, 2008), compared and were similar. The neighbor-joining tree was presented in the text. The Fitch-Margoliash algorithm was used to add the distances to the bootstrapped trees. The SeqMatch program on the RDP website was used (Cole et al., 2007) to identify the taxonomic classifications if the $16 \mathrm{~S}$ rRNA gene sequence similarity to known microorganisms was less than $95 \%$.

To examine the richness of the archaeal community in the bioaugmentation culture, rarefaction analysis, Chao1 richness estimates and Shannon indices were constructed using DOTUR

Water Research, Vol. 44, No. 12 (June 2010): pg. 3555-3564. DOI. This article is (c) Elsevier and permission has been granted for this version to appear in e-Publications@Marquette. Elsevier does not grant permission for this article to be further copied/distributed or hosted elsewhere without the express permission from Elsevier. 
NOT THE PUBLISHED VERSION; this is the author's final, peer-reviewed manuscript. The published version may be accessed by following the link in the citation at the bottom of the page.

(Schloss and Handelsman, 2005). Operational taxonomic units (OTUs) were defined as sequence groups in which sequences differed by $2 \%$ or less.

\subsubsection{Nucleotide sequence accession numbers}

Sequences from the clone library described above were deposited in the GenBank database under accession numbers GU196151-GU196192.

\section{Results}

\subsection{Bioaugmentation culture archaeal community analysis}

An archaeal clone library was constructed for the bioaugmentation culture. Of the 50 sequences, 8 were chimeric and removed from further analysis. The rare faction curve (see Fig. 1) indicated that the archaeal coverage was 83\% (Chao1 richness estimates). Also, the Shannon indices showed that the archaeal clone library was not very heterogeneous (1.25).

Phylogenetic analysis of Archaea in the bioaugmentation culture (see Fig. 2) showed sequences that were related to three methanogenic genera (Methanosaeta, Methanoculleus, and Methanospirillum). Nine sequences grouped in the genus Methanosaeta ( $96 \%$ sequence similarity) and accounted for $21 \%$ of the Archaean sequences sampled. According to the SMA assay results, the activity against acetate was relatively low (SMA $=0.25 \pm 0.07 \mathrm{~mL}$ $\mathrm{CH}_{4} / \mathrm{g}$ VSS-h) even though Methanosaeta was found in high relative abundance.

Because $\mathrm{H}_{2}$ and $\mathrm{C} \mathrm{O}_{2}$ were fed to the bioaugmentation culture, it was anticipated that most of the methanogen16S rRNA gene sequences would relate to $\mathrm{H}_{2}$ utilizers. But only one sequence (C4$46 \mathrm{~A}$ ) was closely related to the $\mathrm{H}_{2}$-utilizer Methanospirillum hungatei (98\% sequence similarity, GenBank accession number: M60880) and only one sequence ( $\mathrm{C} 4-10 \mathrm{~A})$ was closely related to the $\mathrm{H}_{2}$-utilizer Methanoculleus sp. $d m 2$ ( $97 \%$ sequence similarity, GenBank accession

Water Research, Vol. 44, No. 12 (June 2010): pg. 3555-3564. DOI. This article is (C Elsevier and permission has been granted for this version to appear in e-Publications@Marquette. Elsevier does not grant permission for this article to be further copied/distributed or hosted elsewhere without the express permission from Elsevier. 
number: AJ550158). Although these sequences accounted for only $5 \%$ of the clone library, the average SMA value against $\mathrm{H}_{2}$ was relatively high ( $47 \pm 30 \mathrm{~mL} \mathrm{CH}_{4} / \mathrm{g}$ VSS-h). It is possible that the unknown Archaean sequences discussed below that made up $74 \%$ of the community were related to $\mathrm{H}_{2}$ utilizers.

A number of unknown Archaean sequences were found. For example, 14 sequences could only be classified as Euryarchaeota (33\% of the community) and were most similar to an uncultured clone sequenced from a municipal mesophilic anaerobic digester (99\% similarity) (Chouari et al., 2005). In addition, 17sequences could only be placed in the phylum Crenarchaeota, class Thermoprotei (41\% of the community) (see Fig. 2). These sequences were most similar to an uncultured clone sequence from leachate in a municipal solid waste landfill (98\% similarity) (Huang et al., 2003).

\subsection{Bioaugmented digester performance}

\subsubsection{Average $\mathrm{CH}_{4}$ production rate and $\mathrm{pH}$}

Average $\mathrm{CH}_{4}$ production rates for bioaugmented and control digesters were similar before and during air addition (see Figs. 3a and $4 a)$. After air addition, however, the bioaugmented digesters produced significantly more $\mathrm{CH}_{4}$ than the respective controls $(p<0.05)$. The higher $\mathrm{CH}_{4}$ production rate for bioaugmented digesters was evident on Days 25-170 for MS systems (see Fig. 3a) and Days 45-70 for WW systems (see Fig. 4a). For MS systems, the average bioaugmented $\mathrm{CH}_{4}$ production rate was approximately $60 \%$ greater than that of the nonbioaugmented controls during this period. For WW systems, the bioaugmented $\mathrm{CH}_{4}$ production rate was approximately $25 \%$ greater. It should be noted that the apparent decrease in $\mathrm{CH}_{4}$ production rate on Day 148 for the MS systems was due to leaking septa. These septa were replaced and the measured average $\mathrm{CH}_{4}$ production increased in both bioaugmented and control digesters from Day 155 to 161 (27 \pm 3 $\mathrm{mL} \mathrm{CH}_{4}$ /day in the control and $28 \pm 2 \mathrm{~mL} \mathrm{CH}_{4}$ /day in the bioaugmented digesters).

For both MS and WW systems, the average $\mathrm{pH}$ of all digesters was approximately 7.20 before air addition. The $\mathrm{pH}$ then decreased

Water Research, Vol. 44, No. 12 (June 2010): pg. 3555-3564. DOI. This article is @ Elsevier and permission has been granted for this version to appear in e-Publications@Marquette. Elsevier does not grant permission for this article to be further copied/distributed or hosted elsewhere without the express permission from Elsevier. 
during and immediately after air addition with the lowest average $\mathrm{pH}$ values of 6.60 observed between Days 16 and 18 and between Days 39 and 49 for MS and WW systems, respectively. Subsequently, digester $\mathrm{pH}$ values increased to 7 or greater.

\subsubsection{Effluent SCOD}

The average effluent SCOD from all digesters significantly increased after air addition, peaking at approximately $5000 \mathrm{mg} / \mathrm{L}$ (see Figs. $3 b$ and $4 b$ ). Subsequently, the average SCOD decreased below $2000 \mathrm{mg} / \mathrm{L}$, with the decrease more rapid in bioaugmented systems as compared to controls (see Figs. $3 b$ and $4 b$ ).

For MS systems, the average SCOD decreased in the bioaugmented digesters from $4000 \mathrm{mg} / \mathrm{L}$ (Day 30) to $600 \mathrm{mg} / \mathrm{L}$ during a 2.5-month period, and remained relatively low and constant for the remainder of the investigation (see Fig. 3b). In contrast, the average effluent SCOD of the non-bioaugmented digesters remained greater than 2000 mg/L for over five months, as can be seen in Fig. 3b. In addition, effluent SCOD from the non-bioaugmented digesters was significantly higher than that of the bioaugmented digesters at the conclusion of the investigation $(1540 \pm 290 \mathrm{mg} / \mathrm{L}$ versus $780 \pm 210$ $\mathrm{mg} / \mathrm{L}$, respectively).

For WW systems, the high SCOD concentrations persisted during a recovery period of only three months in contrast to the fivemonth recovery for MS systems (see Fig.4b). After Day 120, both bioaugmented and control digesters exhibited low average SCOD concentrations of $200 \mathrm{mg} / \mathrm{L}$ in WW systems (see Fig.4b).

\subsubsection{Effluent propionate}

Effluent propionate concentrations from all digesters increased from less than 600 to greater than $1000 \mathrm{mg} / \mathrm{L}$ during the four-week period after air was added, then began to decrease (see Figs. 3c and 4c). For MS systems, propionic acid in bioaugmented digesters eventually decreased to $60 \pm 40 \mathrm{mg} / \mathrm{L}$ (Day 97), but lingered in control digesters and did not decrease until Day 124 (see Fig.3c). For WW systems, on the other hand, bioaugmented and control digesters

Water Research, Vol. 44, No. 12 (June 2010): pg. 3555-3564. DOI. This article is @ Elsevier and permission has been granted for this version to appear in e-Publications@Marquette. Elsevier does not grant permission for this article to be further copied/distributed or hosted elsewhere without the express permission from Elsevier. 
exhibited similar effluent propionate concentrations over time (see Fig.4c).

\subsubsection{Recovery periods}

For comparison, recovery periods were defined as the time required after air addition for the average effluent concentration of SCOD or propionate to decrease below specified threshold concentrations. After the recovery period, no subsequent increase above the threshold concentration was observed. For SCOD, threshold concentrations of $1 \mathrm{~g} / \mathrm{L}$ and $2 \mathrm{~g} / \mathrm{L}$ were chosen. For propionate, a threshold concentration of $200 \mathrm{mg} / \mathrm{L}$ was employed.

The recovery periods were significantly shorter for bioaugmented digesters in comparison to controls for MS systems ( $p<$ 0.05), but were not shorter for WW systems (see Fig.5). MS bioaugmented digesters achieved an SCOD concentration below $2 \mathrm{~g} / \mathrm{L}$ over 80 days (i.e., 8 SRTs) before the controls (see Fig.5); in addition, the propionic acid concentrations in bioaugmented digesters declined below $200 \mathrm{mg} / \mathrm{L}$ approximately 70 days before that of the controls (Day $90 \pm 0$ versus Day $157 \pm 18$ ). In contrast, the WW bioaugmented and non- bioaugmented digesters both recovered approximately 2 months after oxygen exposure.

\section{Discussion}

Sequences most similar to those of $\mathrm{H}_{2}$-utilizing methanogens (Methanosaeta, Methanoculleus, and Methanospirillum) were found in the bioaugmentation culture, as expected. Sequences grouped in the genus Methanosaeta were also found, and accounted for $21 \%$ of the Archaean sequences sampled. These acetoclastic methanogens have also been found in other anaerobic treatment systems (Macario and de Macario, 1988; Grotenhuis et al., 1991; Raskin et al., 1995; Griffin et al., 1998; Sekiguchi et al., 1998; McHugh et al., 2003; Leclerc et al., 2004). Glucose in the feed to the bioaugmentation culture ostensibly resulted in the presence of acetoclastic methanogens in the $\mathrm{H}_{2}$-rich environment. Fernandez et al. (2000) found that Methanosaeta accounted for approximately $20 \%$ of the total methanogen community in some anaerobic digesters fed glucose as the sole carbon source.

Water Research, Vol. 44, No. 12 (June 2010): pg. 3555-3564. DOI. This article is @ Elsevier and permission has been granted for this version to appear in e-Publications@Marquette. Elsevier does not grant permission for this article to be further copied/distributed or hosted elsewhere without the express permission from Elsevier. 
A large majority of the clones (i.e., 74\%) were unknown Archaean sequences. For example, 33\% of the sequences could only be classified as Euryarchaeota and were most similar to an uncultured clone sequenced from a municipal mesophilic anaerobic digester ( $99 \%$ similarity) (Chouari et al., 2005). In addition, $41 \%$ of the clones could only be placed in the phylum Crenarchaeota, class Thermoprotei. These sequences were most similar to an uncultured clone sequence from leachate in a municipal solid waste landfill ( $98 \%$ similarity) (Huang et al., 2003). The unknown Archaean sequences could not be further classified taxonomically and it is difficult to suggest what role they play in the microbial community. However, the Euryarchaeota could be methanogens.

Bioaugmentation of an aerobic processes has been reported to improve degradation of specific organics, start-up of new digesters, odor reduction, and recovery of organically over-loaded systems at laboratory scale. When we perturbed two different anaerobic digester sets (MS and WW) by exposing them to air, bioaugmentation with a methanogenic, $\mathrm{H}_{2}$-utilizing culture resulted in higher methane production rates. In addition, SCOD concentrations decreased more rapidly in bioaugmented versus non-bioaugmented digesters. O'Flaherty et al. (1999) and O'Flaherty and Colleran (1999) also found that bioaugmentation increased the COD removal rate in anaerobic systems when toxicity was exerted; adding sulfate-acclimated biomass resulted in a $58 \%$ increase in steady-state COD removal for a laboratory anaerobic hybrid reactor treating high-sulfate wastewater (concentration of $4 \mathrm{~g} / \mathrm{L} ; \mathrm{COD} /$ sulfate ratio of $3: 1$ ).

When effluent propionate concentrations and recovery periods were compared, bioaugmentation outcomes varied. Bioaugmentation resulted in significantly shorter recovery periods for MS systems, for which non-bioaugmented controls continued to produce chronically high, lingering propionate concentrations after the toxic event. In contrast, non-bioaugmented WW systems did not accumulate lingering high propionate concentrations, and bioaugmentation did not result in significantly shorter recovery. The addition of $\mathrm{H}_{2}$ utilizers ostensibly reduced digester $\mathrm{H}_{2}$ concentration, resulting in more complete propionate degradation in MS systems. The contradiction in MS and

Water Research, Vol. 44, No. 12 (June 2010): pg. 3555-3564. DOI. This article is @ Elsevier and permission has been granted for this version to appear in e-Publications@Marquette. Elsevier does not grant permission for this article to be further copied/distributed or hosted elsewhere without the express permission from Elsevier. 
WW results may be due to differences in microbial communities for the two digester inocula (MS and WW) employed. Others reported that recovery periods of anaerobic digesters subjected to organic overload differed based upon the microbial communities initially present (Hashsham et al., 2000; Fernandez et al., 2000). Microbial communities in which the number of individual members is approximately the same (i.e., high evenness) have been shown to accomplish higher substrate conversion when exposed to high-salts stress as compared to communities in which a few organisms dominate the population(i.e., low evenness) (Wittebolle et al., 2009). It is possible that the MS system microbial community could rapidly adapt after the toxic event to degrade propionate, whereas the WW system could not.

Therefore, the microbial community structure (i.e., richness, evenness, etc.) within an existing biological system is just as important as the community structure of any culture added when bioaugmentation is practiced. Digester microbial communities before bioaugmentation were not analyzed herein. In one review of laboratory and full-scale aerobic literature, $30 \%$ of the reports showed no benefit when bioaugmentation was practiced (Stephenson and Stephenson, 1992). One reason for the unsuccessful applications may be because biological systems with rapidly adaptable microbial communities will not benefit from bioaugmentation, whereas systems with low microbial diversity or evenness may benefit greatly.

\section{Conclusions}

Bioaugmentation with an $\mathrm{H}_{2}$-utilizing culture is a potential tool to decrease the recovery period and increase biogas production of some anaerobic digesters after a toxic event. Bioaugmentation resulted in decreased recovery times for digesters that tended to produce chronically high, lingering propionate concentrations after air exposure. In contrast, recovery time was not significantly shortened for digesters that did not produce lingering propionate. This contradiction may be due to differences between microbial communities of the two digester inocula employed. Digesters already containing rapidly adaptable microbial communities may not benefit from bioaugmentation, whereas other digesters with poorly adaptable

Water Research, Vol. 44, No. 12 (June 2010): pg. 3555-3564. DOI. This article is (c Elsevier and permission has been granted for this version to appear in e-Publications@Marquette. Elsevier does not grant permission for this article to be further copied/distributed or hosted elsewhere without the express permission from Elsevier. 
microbial communities may benefit greatly. Analysis of microbial communities in both bioaugmentation cultures and digester biomass is suggested to develop bioaugmentation applications. In the future, the community structures of various digesters as well as bioaugmentation cultures should be determined and their response to bioaugmentation during toxicity events or periods of elevated propionate should be compared.

\section{Notes}

- $\quad$ a Department of Civil and Environmental Engineering, Water Quality Center, Marquette University, 1515 W. Wisconsin Ave., Milwaukee, WI 53233,USA

- b Department of Biological Sciences, Marquette University, Milwaukee, WI 53233,USA

- c Department of Mathematics, Statistics and Computer Science, Marquette University, Milwaukee, WI 53233,USA

- Corresponding author. Tel.: + 1414288 5733; fax: + 1414 288 7521. E-mail address: daniel.zitomer@marquette.edu (D.H. Zitomer).

\section{Acknowledgements}

- This research was supported by funding from the Naulin Foundation and Marquette University.

\section{References}

Abeysinghe, D.H., De Silva, D.G.V., Stahl, D.A., Rittmann, B.E., 2002. The effectiveness of bioaugmentation in nitrifying systems stressed by a washout condition and cold temperatures. Water Environment Research 74 (2), 187-199.

Ahring, B.K., Christiansen, N., Mathrani, I., Hendriksen, H.V., Macario, A.J.L., Conway de Macario, E., 1992. Introduction of a de novo bioremediation ability, aryl reductive dechlorination, into anaerobic granular sludge by inoculation of sludge with Desulfomonile tiedjei. Applied and Environmental Microbiology 58 (11), 3677-3682.

Water Research, Vol. 44, No. 12 (June 2010): pg. 3555-3564. DOI. This article is @ Elsevier and permission has been granted for this version to appear in e-Publications@Marquette. Elsevier does not grant permission for this article to be further copied/distributed or hosted elsewhere without the express permission from Elsevier. 
NOT THE PUBLISHED VERSION; this is the author's final, peer-reviewed manuscript. The published version may be accessed by following the link in the citation at the bottom of the page.

Altschul, S.F., Madden, T.L., Schaffer, A.A., Zhang, J., Zhang, Z., Miller, W., Lipman, D.J., 1997. Gapped BLAST and PSI-BLAST: a new generation of protein database search programs. Nucleic Acids Research 25, 3389-3402.

American Public Health Association (APHA), American Waterworks Association (AWWA), Water Environment Federation (WEF)., 1998. Standard Methods for the Examination of Water and Wastewater, 20th ed. McGraw-Hill Companies, Inc., NewYork, NY.

Angelidaki, I., Alves, M., Bolzonella, D., Borzacconi, L., Campos, L., Guwy, A., Jenicek, P., Kalyuzhnui, S., Van Lier, J., October 9-10, 2007. Anaerobic Biodegradation, Activity and Inhibition (ABAI). Task Group Meeting. Prague, Czech Republic. http://www.er.dtu.dk/publications/fulltext/2007/MR2007-147.pdf (accessed 27.07.09).

Angelidaki, I., Ahring, B.K., 2000. Methods for increasing the biogas potential from the recalcitrant organic matter contained in manure. Water Science and Technology 41 (3), 189-194.

Charest, A., Bisaillon, J.G., Lepine, F., Beaudet, R., 1999. Removal of phenolic compounds from a petrochemical effluent with a methanogenic consortium. Canadian Journal of Microbiology 45 (3), 235-241.

Chouari, R., Le Paslier, D., Daegelen, P., Ginestet, P., Weissenbach, J., Sghir, A., 2005. Novel predominant archaeal and bacterial groups revealed by molecular analysis of an anaerobic sludge digester. Environmental Microbiology 7 (8), 1104-1115.

Cirne, D.G., Bjornsson, L., Alves, M., Mattiasson, B., 2006. Effects of bioaugmentation by an anaerobic lipolytic bacterium on anaerobic digestion of lipid-rich waste. Journal of Chemical Technology and Biotechnology 81, 1745-1752.

Coates, J.D., Coughlan, M.F., Colleran, E., 1996.Simple method for the measurement of the hydrogenotrophic methanogenic activity of anaerobic sludges. Journal of Microbiological Methods 26, 237-246.

Cole, J.R., Chai, B., Farris, R.J., Wang, Q., Kulam-Syed-Mohideen, A.S., McGarrell, D.M., Bandela, A.M., Cardenas, E., Garrity, G.M., Tiedje, J.M., 2007. The ribosomal database project (RDP-II):introducing myRDP space and quality controlled public data. Nucleic Acids Research 35 (Database Issue), D169-D172.

Water Research, Vol. 44, No. 12 (June 2010): pg. 3555-3564. DOI. This article is (C) Elsevier and permission has been granted for this version to appear in e-Publications@Marquette. Elsevier does not grant permission for this article to be further copied/distributed or hosted elsewhere without the express permission from Elsevier. 
NOT THE PUBLISHED VERSION; this is the author's final, peer-reviewed manuscript. The published version may be accessed by following the link in the citation at the bottom of the page.

Cole, J.R., Chai, B., Farris, R.J., Wang, Q., Kulam, S.A., McGarrell, D.M., Garrity, G.M., Tiedje, J.M., 2005. The ribosomal database project (RDPII): sequences and tools for high-through put rRNA analysis. Nucleic Acids Research 33 (Database Issue), D294-D296.

Deflaun, M.F., Steffan, R.J., 2002. Bioaugmentation. In: Bitton, G. (Ed.), Encyclopedia of Environmental Microbiology, vol. 1. Wiley-Interscience, New York, NY, pp. 434-442.

DeLong, E.F., 1992. Archaea in costal marine environments. Proceedings of the National Academy of Sciences 89, 5685-5689.

Duran, M., Tepe, N., Yurtsever, D., Punzi, V.L., Bruno, C., Mehta, R. J., 2006. Bioaugmenting anaerobic digestion of biosolids with selected strains of Bacillus, Pseudomonas, and Actinomycetes species for increased methanogenesis and odor control. Applied Microbiology and Biotechnology 73, 960-966.

El Fantroussi, S., Agathos, S.N., 2005. Is bioaugmentation a feasible strategy for pollutant removal and site remediation? Current Opinion in Microbiology 8 (3), 268-275.

Felsenstein, J., 2005. PHYLIP (Phylogeny Inference Package) Version 3.6. Distributed by the author. Department of Genome Sciences, University of Washington, Seattle.

Fernandez, A.S., Hashsham, S.A., Dollhopf, S.L., Raskin, L., Glagoleva, O., Dazzo, F.B., Hickey, R.F., Criddle, C.S., Tiedje, J.M., 2000. Flexible community structure correlates with stable community function in methanogenic bioreactor communities perturbed by glucose. Applied and Environmental Microbiology 66 (9), 4058-4067.

Griffin, M.E., McMahon, K.D., Mackie, R.I., Raskin, L., 1998. Methanogenic population dynamics during start-up of anaerobic digesters treating municipal solid waste and biosolids. Biotechnology and Bioengineering 57 (3), 342-355.

Grotenhuis, J.T.C., Smit, M., Plugge, C.M., Yuansheng, X., van Lammeren, A.A.M., Stams, A.J.M., Zehnder, A.J.B., 1991. Bacteriological composition and structure of granular sludge adapted to different substrates. Applied and Environmental Microbiology 57 (7), 19421949.

Water Research, Vol. 44, No. 12 (June 2010): pg. 3555-3564. DOI. This article is @ Elsevier and permission has been granted for this version to appear in e-Publications@Marquette. Elsevier does not grant permission for this article to be further copied/distributed or hosted elsewhere without the express permission from Elsevier. 
NOT THE PUBLISHED VERSION; this is the author's final, peer-reviewed manuscript. The published version may be accessed by following the link in the citation at the bottom of the page.

Guiot, S.R., Tartakovsky, B., Lanthier, M., Levesque, M.J., Manuel, M.F., Beaudet, R., Greer, C.W., Villemur, R., 2002. Strategies for augmenting the pentachlorophenol degradation potential of UASB anaerobic granules. Water Science and Technology 45 (10), 35-41.

Guiot, S.R., Tawfiki-Hajji, K., Lepine, F., 2000. Immobilization strategies for bioaugmentation of anaerobic reactors treating phenolic compounds. Water Science and Technology 42 (5-6), 245-250.

Hashsham, S.A., Fernandez, A.S., Dollhopf, S.L., Dazzo, F.B., Hickey, R.F., Tiedje, J.M., Criddle, C.S., 2000.Parallel processing of substrate correlates with greater functional stability in methanogenic bioreactor communities perturbed by glucose. Applied and Environmental Microbiology 66 (9), 4050-4057.

Head, M.A., Oleszkiewicz, J.A., 2005. Bioaugmentation with nitrifying bacteria acclimated to different temperatures. Journal of Environmental Engineering 131 (7), 1046-1051.

Horber, C., Christiansen, N., Arvin, E., Ahring, B.K., 1998. Improved dechlorinating performance of upflow anaerobic sludge blanket reactors by incorporation of Dehalospirillum multivorans into granular sludge. Applied and Environmental Microbiology 64 (5), 1860-1863.

Huang, L., Chen, Y., Zhou, H., Luo, S., Lan, C., Qu, L., 2003. Characterization of methanogenic Archaea in the leachate of a closed municipal solid waste landfill. FEMS Microbiology Ecology 46, 171-177.

Leclerc, M., Delgenes, J., Godon, J., 2004. Diversity of the archaeal community in 44 anaerobic digesters as determined by single strand conformation polymorphism analysis and 16S rDNA sequencing. Environmental Microbiology 6 (8), 809-819.

Lynch, N., Daniels, L., Parkin, G.F., 1987. Bioaugmentation of stressed anaerobic filters with methanogenic enrichment cultures. In: Proceedings of the 42 nd Industrial Waste Conference. Purdue University, West Lafayette, Indiana, pp. 285-296.

Macario, A.J.L., de Macario, E.C., 1988.Quantitative immunologic analysis of the methanogenic flora of digestors reveals a considerable diversity. Applied and Environmental Microbiology 54 (1), 79-86.

Water Research, Vol. 44, No. 12 (June 2010): pg. 3555-3564. DOI. This article is @ Elsevier and permission has been granted for this version to appear in e-Publications@Marquette. Elsevier does not grant permission for this article to be further copied/distributed or hosted elsewhere without the express permission from Elsevier 
NOT THE PUBLISHED VERSION; this is the author's final, peer-reviewed manuscript. The published version may be

accessed by following the link in the citation at the bottom of the page.

McCarty, P.L., Smith, D.P., 1986. Anaerobic wastewater treatment. Environmental Science and Technology 20 (12), 1200-1206.

McHugh, S., Carton, M.,Mahony, T., O'Flaherty, V., 2003. Methanogenic population structure in a variety of anaerobic bioreactors. FEMS Microbiology Letters 219, 297-304.

Mladenovska, Z., Ishoy, T., Mandiralioglu, A., Westermann, P., Ahring, B., 2001. Bioaugmentation of a mesophilic biogas reactor by anaerobic xylanolytic- and cellulolytic bacteria. In: Proceedings of the Ninth World Congress on Anaerobic Digestion, Antwepen, Belgium, pp. 183188.

Nielsen, H.B., Mladenovska, Z., Ahring, B.K., 2007. Bioaugmentation of a two-stage thermophilic $\left(68^{\circ} \mathrm{C} / 55^{\circ} \mathrm{C}\right)$ anaerobic digestion concept for improvement of the methane yield from cattle manure. Biotechnology and Bioengineering 97 (6), 1638-1643.

O'Flaherty, V., Colleran, E., 1999. Effect of sulphate addition on volatile fatty acid and ethanol degradation in an anaerobic hybrid reactor. I: process disturbance and remediation. Bioresource Technology 68, 101-107.

O'Flaherty, V., Colohan, S., Mulkerrins, D., Colleran, E., 1999. Effect of sulphate addition on volatile fatty acid and ethanol degradation in an anaerobic hybrid reactor. II: microbial interactions and toxic effects. Bioresource Technology 68, 109-120.

Rambaut, A., 2008. FigTree: Tree Figure Drawing Tool. Version 1.1.2. Institute of Evolutionary Biology. University of Edinburgh. http://tree.bio.ed.ac.uk/software/figtree.

Raskin, L., Zheng, D., Griffin, M.E., Stroot, P.G., Misra, P., 1995. Characterization of microbial communities in anaerobic bioreactors using molecular probes. Antonie Van Leeuwenhoek 68, 297-308.

Rittmann, B.E., Whiteman, R., 1994.Bioaugmentation: a coming of age. Water Quality International 1, 12-16.

Sambrook, J., Russell, D.W., 2001. Molecular Cloning: A Laboratory Manual, third. Cold Spring Harbor Laboratory Press, Cold Springs, NY.

Saravanane, R., Murthy, D.V.S., Krishnaiah, K., 2001a. Bioaugmentation and anaerobic treatment of pharmaceutical effluent in fluidized bed reactor. Journal of Environmental Science andHealth 36 (5), 779-791.

Water Research, Vol. 44, No. 12 (June 2010): pg. 3555-3564. DOI. This article is (C) Elsevier and permission has been granted for this version to appear in e-Publications@Marquette. Elsevier does not grant permission for this article to be further copied/distributed or hosted elsewhere without the express permission from Elsevier. 
NOT THE PUBLISHED VERSION; this is the author's final, peer-reviewed manuscript. The published version may be accessed by following the link in the citation at the bottom of the page.

Saravanane, R., Murthy, D.V.S., Krishnaiah, K., 2001b. Bioaugmentation and treatment of cephalexin drug-based pharmaceutical effluent in an upflow anaerobic fluidized bed system. Bioresource Technology 76, 279-281.

Satoh, H., Okabe, S., Yamaguchi, Y., Watanabe, Y., 2003. Evaluation of the impact of bioaugmentation and biostimulation by in situ hybridization and microelectrode. Water Research 37, 2206-2216.

Schloss, P.D., Handelsman, J., 2005. Introducing DOTUR, a computer program for defining operational taxonomic units and estimating species richness. Applied and Environmental Microbiology 71 (3), 1501-1506.

Sekiguchi, Y., Kamagata, Y., Syutsubo, K., Ohashi, A., Harada, H., Nakamura, K., 1998. Phylogenetic diversity of mesophilic and thermophilic granular sludges determined by $16 \mathrm{~S}$ rRNA gene analysis. Microbiology $144,2655-2665$.

Singer, A.C., van der Gast, C.J., Thompson, I.P., 2005. Perspectives and vision for strain selection in bioaugmentation. Trends in Biotechnology 23 (2), 74-77.

Stephenson, D., Stephenson, T., 1992. Bioaugmentation for enhancing biological wastewater treatment. Biotechnology Advances 10, 549559.

Tartakovsky, B., Levesque, M.-J., Dumortier, R., Beaudet, R., Guiot, S.R., 1999. Biodegradation of pentachlorophenol in a continuous anaerobic reactor augmented with Desulfitobacterium frappieri PCP-1. Applied and Environmental Microbiology 65 (10), 4357-4362.

Tawfiki Hajji, K., Lepine, F., Bisaillon, J.G., Beaudet, R., Hawari, J., Guiot, S.R., 2000. Effects of bioaugmentation strategies in UASB reactors with a methanogenic consortium for removal of phenolic compounds. Biotechnology and Bioengineering 67 (4), 417-423.

Tawfiki Hajji, K., Lepine, F., Bisaillon, J.G., Beaudet, R., 1999. Simultaneous removal of phenol, ortho- and para-cresol by mixed anaerobic consortia. Canadian Journal of Microbiology 45 (4), 318-325.

Tepe, N., Yurtsever, D., Mehta, R.J., Bruno, C., Punzi,V.L., Duran, M., 2008. Odor control during post-digestion processing of biosolids through

Water Research, Vol. 44, No. 12 (June 2010): pg. 3555-3564. DOI. This article is (C) Elsevier and permission has been granted for this version to appear in e-Publications@Marquette. Elsevier does not grant permission for this article to be further copied/distributed or hosted elsewhere without the express permission from Elsevier. 
NOT THE PUBLISHED VERSION; this is the author's final, peer-reviewed manuscript. The published version may be accessed by following the link in the citation at the bottom of the page.

bioaugmentation of anaerobic digestion. Water Science and Technology 57 (4), 589-594.

Van Limbergen, H., Top, E.M., Verstraete, W., 1998. Bioaugmentation in activated sludge: current features and future perspectives. Applied Microbiology and Biotechnology 50, 16-23.

Wittebolle, L., Marzorati, M., Clement, L., Balloi, A., Daffonchio, D., Heylen, K., De Vos, P., Verstraete, W., Boon, N., 2009. Initial community evenness favours functionality under selective stress. Nature 458, 623-626.

\section{Appendix}

Figure 1 Rarefaction curve of archaeal clone library of the bioaugmentation culture.

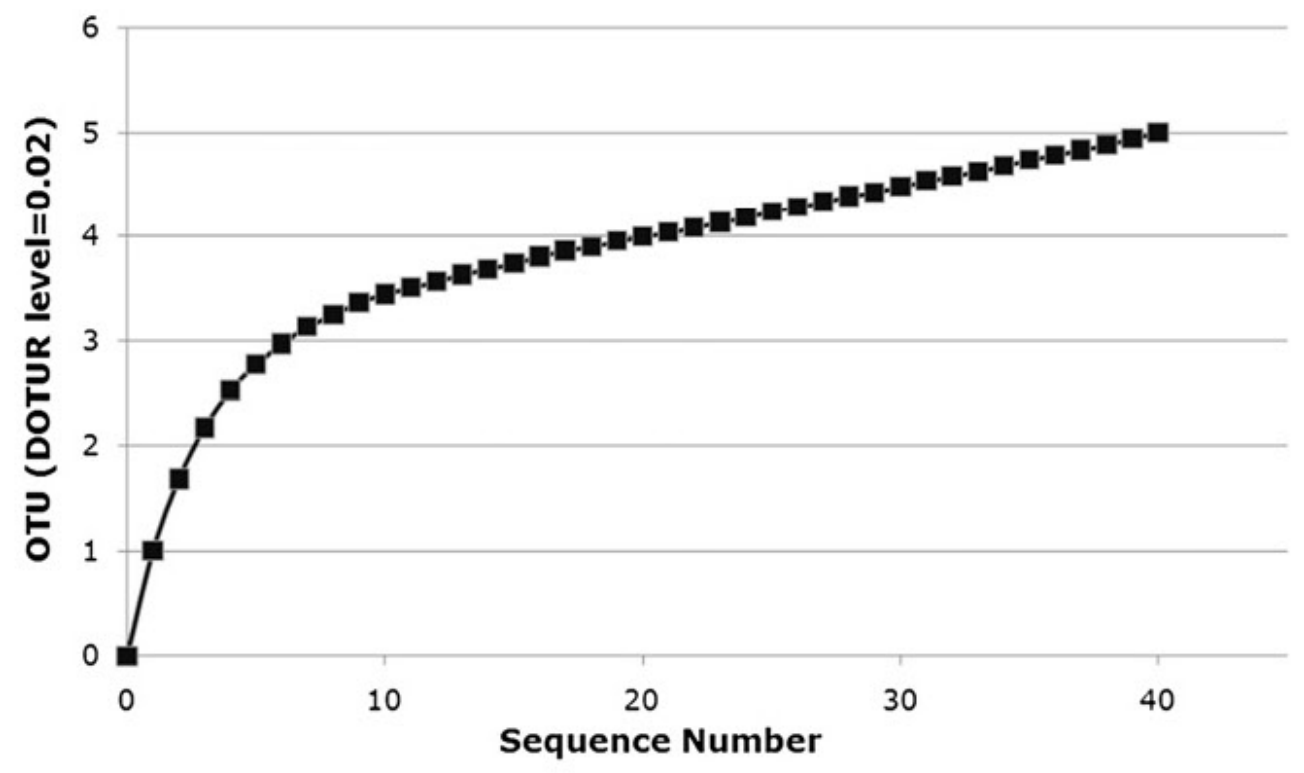

Water Research, Vol. 44, No. 12 (June 2010): pg. 3555-3564. DOI. This article is C Elsevier and permission has been granted for this version to appear in e-Publications@Marquette. Elsevier does not grant permission for this article to be further copied/distributed or hosted elsewhere without the express permission from Elsevier. 
NOT THE PUBLISHED VERSION; this is the author's final, peer-reviewed manuscript. The published version may be accessed by following the link in the citation at the bottom of the page.

Figure 2 Phylogenetic analysis of the bioaugmentation culture archaeal clone library.
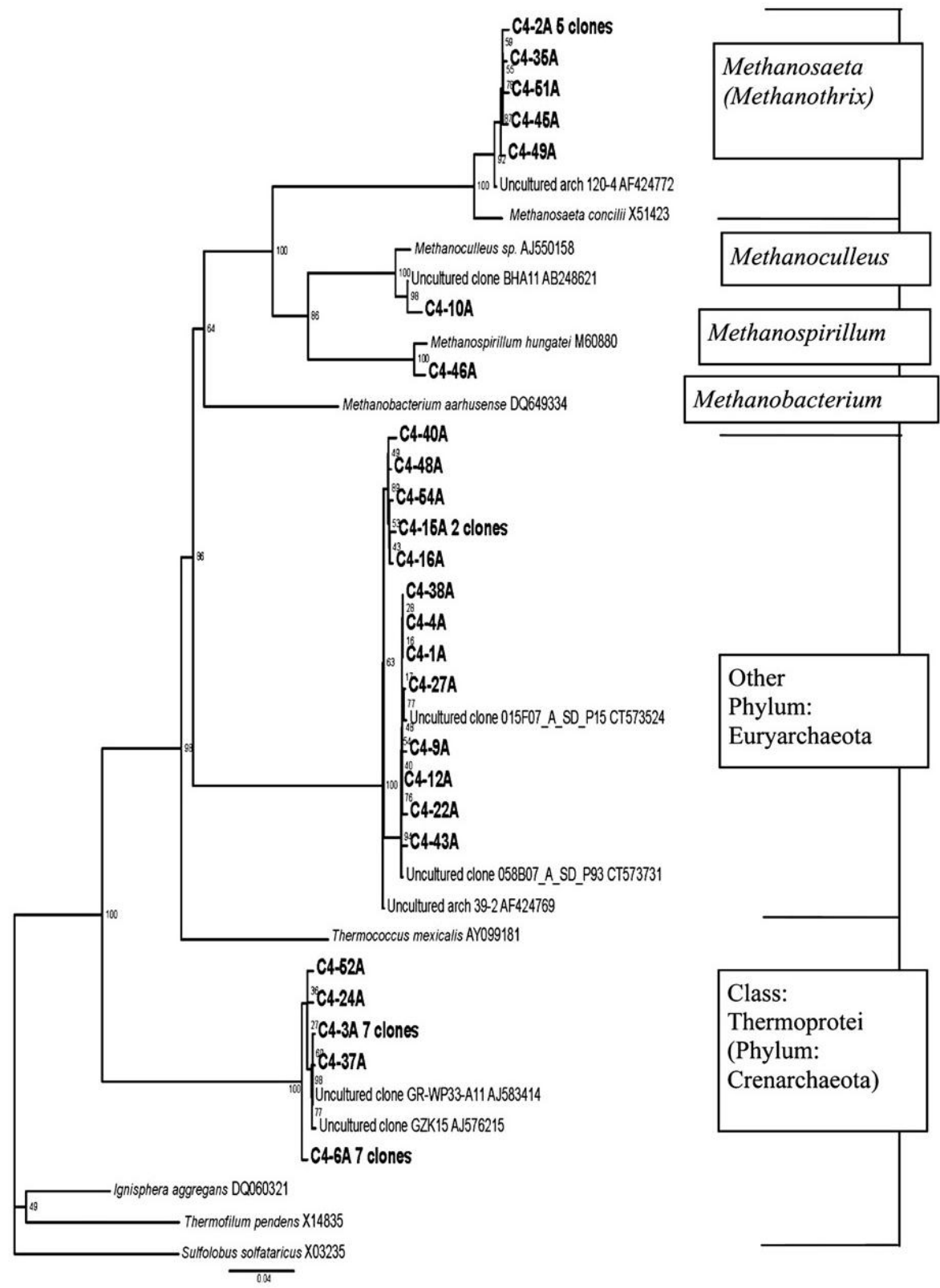

Calculations were based on the neighbor-joining algorithm (bootstrap number $=100$ ). Numbers at node represent bootstrap values. The scale bar represents the number of nucleotide changes per sequence position. The tree was rooted to the organism Sulfolobus solfataricus (X03235).

Water Research, Vol. 44, No. 12 (June 2010): pg. 3555-3564. DOI. This article is @ Elsevier and permission has been granted for this version to appear in e-Publications@Marquette. Elsevier does not grant permission for this article to be further copied/distributed or hosted elsewhere without the express permission from Elsevier. 
NOT THE PUBLISHED VERSION; this is the author's final, peer-reviewed manuscript. The published version may be accessed by following the link in the citation at the bottom of the page.

Figure 3 Results of bioaugmented and control MS digesters.

a

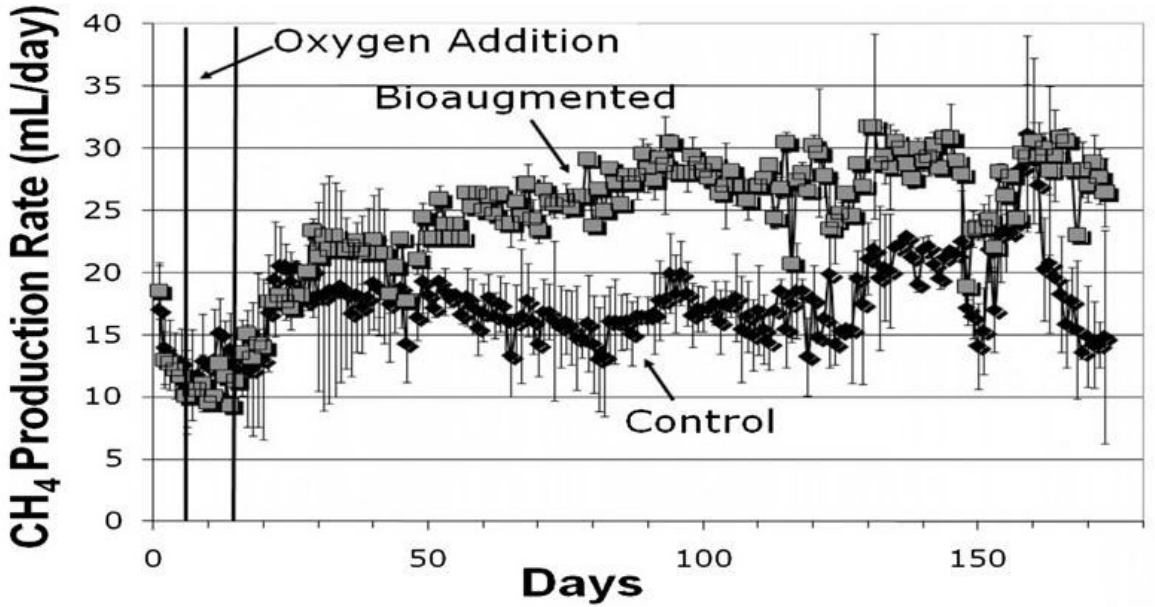

b

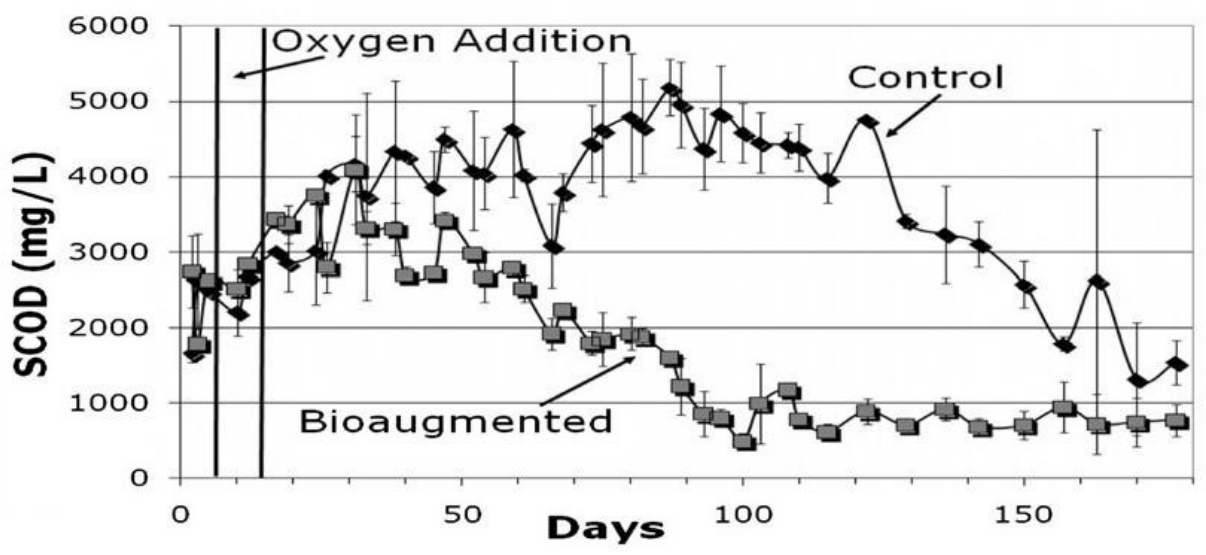

C

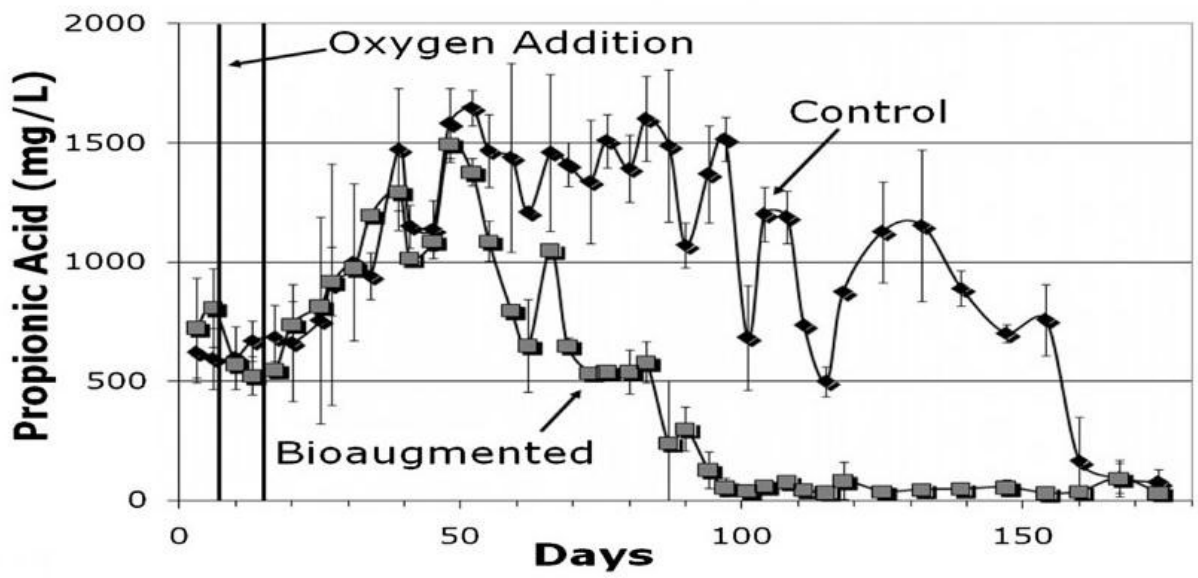

(a) Methane production; (b) SCOD; (c) propionic acid. Error bars represent standard deviation of duplicate digesters.

Water Research, Vol. 44, No. 12 (June 2010): pg. 3555-3564. DOI. This article is @ Elsevier and permission has been granted for this version to appear in e-Publications@Marquette. Elsevier does not grant permission for this article to be further copied/distributed or hosted elsewhere without the express permission from Elsevier. 
NOT THE PUBLISHED VERSION; this is the author's final, peer-reviewed manuscript. The published version may be accessed by following the link in the citation at the bottom of the page.

Figure 4 Results of bioaugmented and control WW digesters.
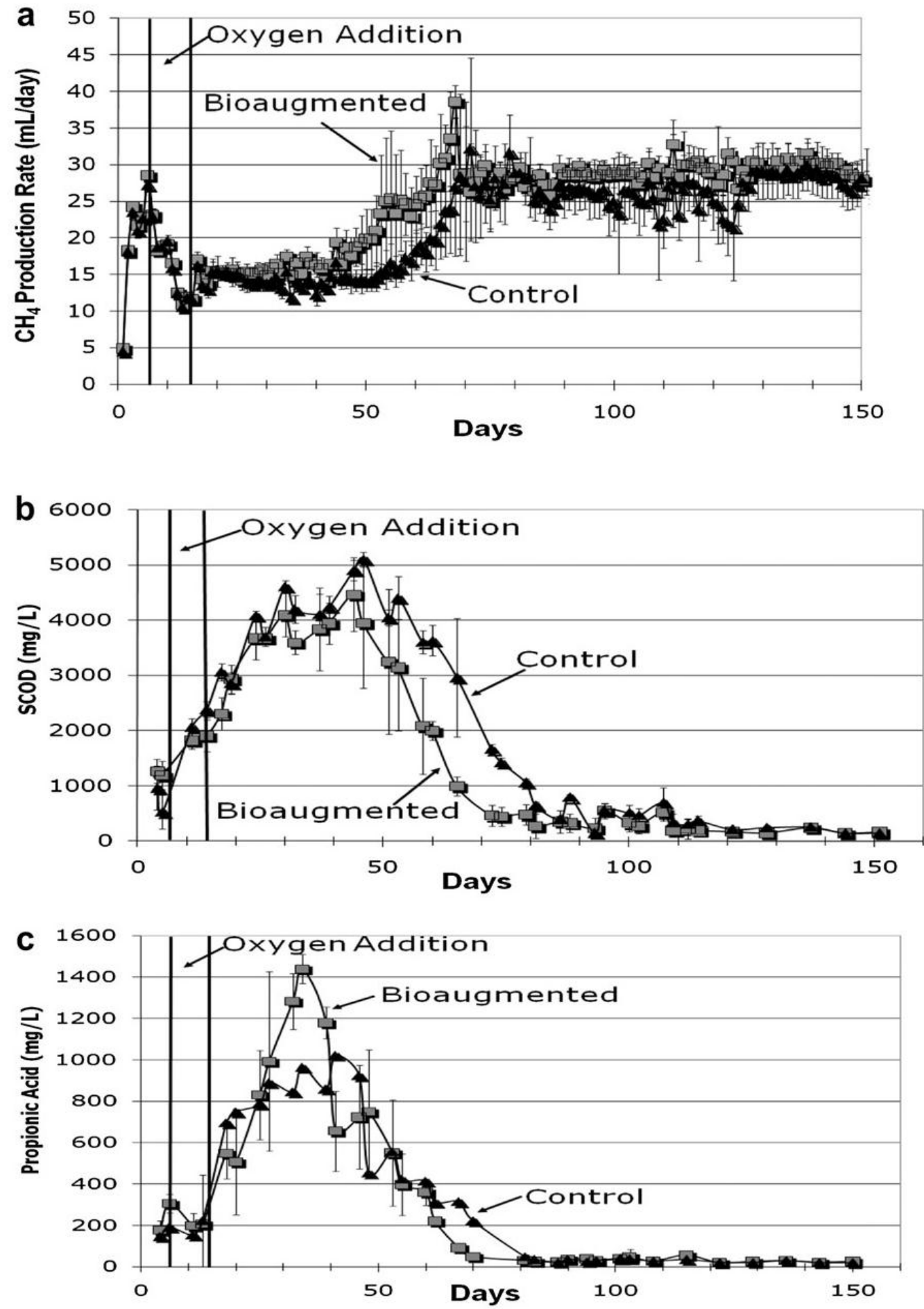

(a) Methane production; (b) SCOD; (c) propionic acid. Error bars represent standard deviation of four replicate digesters.

Water Research, Vol. 44, No. 12 (June 2010): pg. 3555-3564. DOI. This article is @ Elsevier and permission has been granted for this version to appear in e-Publications@Marquette. Elsevier does not grant permission for this article to be further copied/distributed or hosted elsewhere without the express permission from Elsevier. 
NOT THE PUBLISHED VERSION; this is the author's final, peer-reviewed manuscript. The published version may be accessed by following the link in the citation at the bottom of the page.

Figure 5 Comparison of bioaugmented and control system recovery periods.
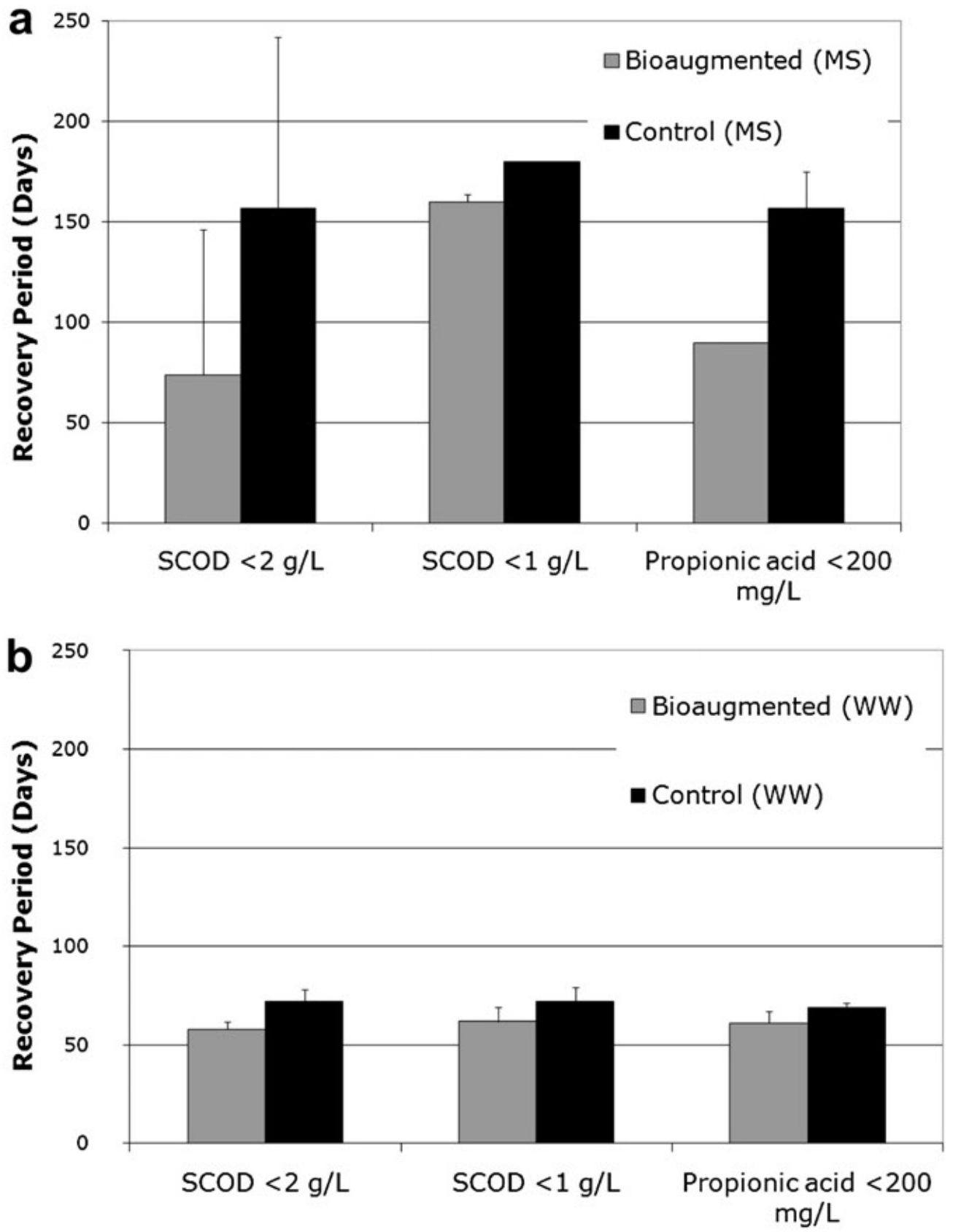

Average bioaugmented and control digester recovery periods for MS systems (a); and WW systems (b). Recovery periods for MS control and bioaugmented systems were different, whereas that for WW systems were not $(p<0.05)$. Error bars represent standard deviation. Some error bars are small and not visible.

Water Research, Vol. 44, No. 12 (June 2010): pg. 3555-3564. DOI. This article is @ Elsevier and permission has been granted for this version to appear in e-Publications@Marquette. Elsevier does not grant permission for this article to be further copied/distributed or hosted elsewhere without the express permission from Elsevier. 